\title{
ORGANOCATALYTIC SYNTHESIS OF AMIDES FROM ALDEHYDES THROUGH $p$-NITRO PHENOL ESTER ACTIVATION
}

\author{
Medikonda Manorajani* and Tatavarti Bhagya Kumar \\ Department of Chemistry, Post Graduate Centre, P.B. Sidharatha Arts \& Science College, \\ Vijayawada, Andhra Pradesh. India. Pin-520010 \\ *E-mail: drmanoranjani@yahoo.com
}

\begin{abstract}
We herein demonstrate an efficient methodology for the amidation from aldehydes through p-nitro phenol ester activation using tetrabutyl ammonium bromide (TBAB) and tetrabutyl hydrogen peroxide (TBHP) in decane. Unlike the routine condensation chemistry using coupling reagents from the carboxylic acids, the present methodology offers advantages such as cheap catalyst, in situ activation from aldehydes that would preclude the stoichiometric chemical waste, a wide substrate scope etc. However, the present methodology suffers from a debilitating drawback that it could not be applied to the aliphatic aldehydes. In addition to the exploration of the catalyst, the electronic and steric factors are studied with appropriate selection of the substrates.

Keywords: Organo catalysis, Amidation, Activated ester, Tetrabutyl ammonium bromide
\end{abstract}

(C) RASĀYAN. All rights reserved

\section{INTRODUCTION}

Ubiquitousness of amide and ester functionality makes the condensation reactions extremely important. ${ }^{1}$ The classical condensation reaction is in between carboxylic acids and nucleophillic amines, alcohols and amino acids to produce amides, esters and peptides respectively. ${ }^{2}$ Interestingly, most of these methods are through the activation of carboxylic acid into an activated form and then nucleophillic acylation.. Needless to mention that to make the activated ester, copious expensive coupling reagents have been developed that would produce stoichiometric amount of waste. ${ }^{3}$ But activation of aldehyde into an activated form for acylation has been recently started and largely being explored using transition metal catalysis and organocatlysis ${ }^{4}$. But, an important activating auxiliary i.e. para nitro phenolic esters, has not been attempted in the context of amide synthesis from aldehydes. ${ }^{5}$ Therefore, we wanted to make the para nitrophenol (PNP) esters in situ from aldehydes and thereby facilitate the amidation and esterification.

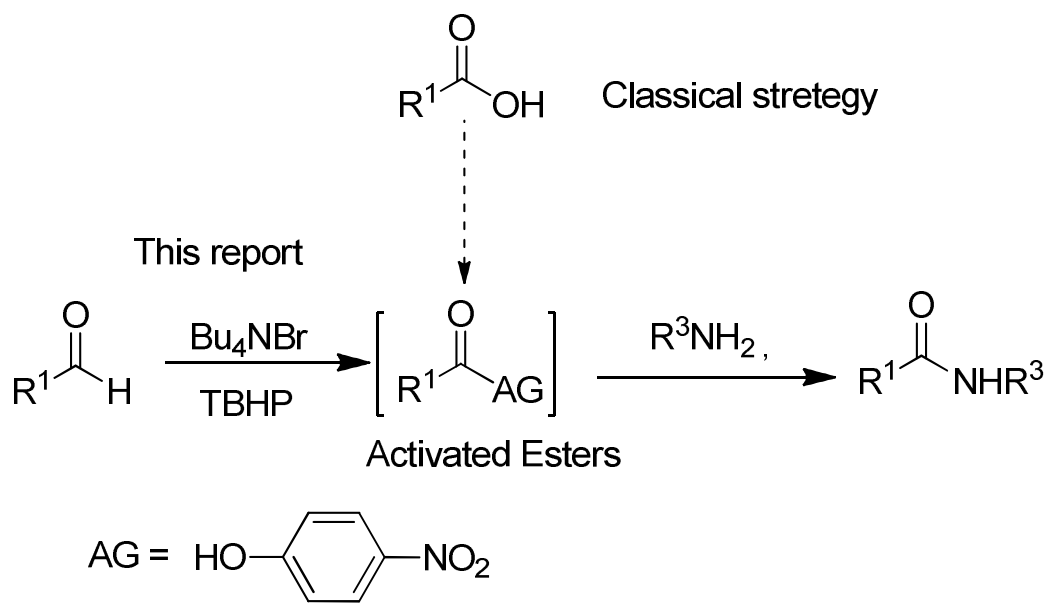

Scheme-1: Synthesis of amides and esters from Aldehydes 


\section{General}

\section{EXPERIMENTAL}

Glassware was dried in an oven and cooled before use. Unless stated otherwise, all the materials obtained from commercial sources were used without any extra purification. Reactions were monitored by TLC on silica gel plates using UV-light and Iodine. The solvents used for recrystallization are distilled using the standard procedure. Evaporation of solvents was conducted under reduced pressure at $50^{\circ} \mathrm{C}$. NMR spectra were reported on a Bruker $400 \mathrm{MHz}$ NMR spectrometer. Chemical shifts $(\delta)$ and coupling constants (J)are given in ppm (parts per million) and $\mathrm{Hz}$ (Hertz), respectively.

\section{Typical procedure for generality of reaction catalyzed by $n-B_{4} \mathrm{NBr}$}

The aldehyde ( $1 \mathrm{mmol}, 1$ equiv.) and para nitrophenol (1.5 mmol, 1.5 equiv.) were added to a $25 \mathrm{~mL}$ round bottom flask charged with a magnetic stirring bar and dissolved in ethyl acetate $(3 \mathrm{~mL})$. To this mixture, $10 \mathrm{~mol} \%$ of $n$-Bu $\mathrm{NBr}(0.1$ equiv) and $5.5 \mathrm{M}$ tert-butyl hydroperoxide (TBHP) in decane (2.0 equiv) were added at room temperature. The reaction mixture was initially stirred at room temperature. It was noticed that the heating at $70^{\circ} \mathrm{C}$ accelerated the reaction. After completion of the reaction, the reaction mixture was cooled to room temperature and then added the respective amine (1.2 equiv.). The reaction was stirred at room temperature. Interestingly, the reaction was found to be complete within 20 min. Then the reaction mixture was further diluted with $10 \mathrm{~mL}$ EtOAc and then washed with $5 \% \mathrm{NaHCO}_{3}$ $(3 \times 10 \mathrm{~mL})$. The product was almost isolated to be pure one, though it was recrystallized as per necessity.

1. N-Benzylbenzamide: yield $91 \%, 193 \mathrm{mg}$; Colorless solid; ${ }^{1} \mathrm{H}$ NMR (400 $\left.\mathrm{MHz}, \mathrm{CDCl}_{3}\right)$ 87.78-7.73 (m, 2H), 7.42-7.30 (m, 4H), 7.36-7.28 (m, 4H), 4.61-4.59 (d, J = 4.0 Hz, 2H)

2. N-Benzyl-4-methoxybenzamide: yield 87\%, 209mg; Colorless solid; ${ }^{1} \mathrm{H}$ NMR (400 MHz, $\left.\mathrm{CDCl}_{3}\right): 3.72(\mathrm{~s}, 3 \mathrm{H}), 4.54-4.56(\mathrm{~d}, 2 \mathrm{H}, J=5.5 \mathrm{~Hz}), 6.84-6.87(\mathrm{~d}, 2 \mathrm{H}, J=7.5 \mathrm{~Hz}), 7.26-7.30(\mathrm{~m}, 5 \mathrm{H})$, $7.69-7.72(\mathrm{~d}, 2 \mathrm{H}, J=7.5 \mathrm{~Hz})$

3. N-Butylbenzamide: yield $82 \%, 145 \mathrm{mg}$; Colorless solid; ${ }^{1} \mathrm{H} \mathrm{NMR} \delta\left(400 \mathrm{MHz}, \mathrm{CDCl}_{3}\right) 7.76-7.74$ $(\mathrm{d}, J=8.3 \mathrm{~Hz}, 2 \mathrm{H}), 7.37-7.51(\mathrm{~m}, 3 \mathrm{H}), 6.35(\mathrm{br}, \mathrm{s}, 1 \mathrm{H}),, 3.42(\mathrm{~m}, J=12.84,2 \mathrm{H}),, 1.62(\mathrm{~m}, J=14.35$, $2 \mathrm{H},), 1.36-1.48(\mathrm{~m}, 2 \mathrm{H}), 0.99(\mathrm{t}, J=6.79,3 \mathrm{H})$

4. N-Butyl-4-nitrobenzamide: yield 91\%, $203 \mathrm{mg}$; Colorless solid; ${ }^{1} \mathrm{H}$ NMR $\delta\left(400 \mathrm{MHz}, \mathrm{CDCl}_{3}\right)$ $8.21-8.00(\mathrm{~d}, J=8.3 \mathrm{~Hz}, 2 \mathrm{H}), 7.92-7.90(\mathrm{~d}, J=8.3,2 \mathrm{H}), 6.25(\mathrm{br}, \mathrm{s}, 1 \mathrm{H}), 3.48(\mathrm{~m}, J=12.84,2 \mathrm{H}), 1.65$ $(\mathrm{m}, J=6.79,2 \mathrm{H}), 1.38-1.52(\mathrm{~m},, 2 \mathrm{H}), 1.0(\mathrm{t}, J=6.55,3 \mathrm{H})$

5. 4-Bromo-N-butylbenzamide: yield 80\%, $204 \mathrm{mg}$; Colorless solid; ${ }^{1} \mathrm{H}$ NMR $\delta\left(400 \mathrm{MHz}, \mathrm{d}_{6}\right.$ DMSO ) 8.00(s, broad, $1 \mathrm{H}), 7.75(\mathrm{~d}, 2 \mathrm{H}, J=7.6), 7.50(\mathrm{~d}, \mathrm{~J}=8.8,2 \mathrm{H}), 3.30(\mathrm{q}, J=12.84,2 \mathrm{H}), 1.55(\mathrm{~m}, J$ $=14.30,2 \mathrm{H}), 1.20-1.48(\mathrm{~m}, 2 \mathrm{H}), 0.95(\mathrm{t}, J=6.79,3 \mathrm{H})$.

6. 4-Bromo-N-(tert-butyl)benzamide: yield $108 \mathrm{mg}(61 \%)$; Colorless solid; ${ }^{1} \mathrm{H}$ NMR $\delta(400 \mathrm{MHz}$, $\left.\mathrm{CDCl}_{3}\right)$ 7.72-7.70 (d, $\left.J=8.1 \mathrm{~Hz}, 2 \mathrm{H}\right), 7.37-7.45(\mathrm{~m}, 3 \mathrm{H}), 5.84(\mathrm{br}, \mathrm{s}, 1 \mathrm{H}),, 1.46(\mathrm{~s}, 9 \mathrm{H})$.

7. Phenyl(piperidin-1-yl)methanone: yield 96\%, $181 \mathrm{mg}$; Colorless oil : ${ }^{1} \mathrm{H}$ NMR $\delta(400 \mathrm{MHz}$, $\left.\mathrm{CDCl}_{3}\right) 7.39$ (brs, 5H), 3.72 (brs, 2H),3.34 (brs, 2H), 1.68 (brs, 4H), 1.52 (br, 2H).

8. (4-Methoxyphenyl)(piperidin-1-yl)methanone:yield 89\%, $195 \mathrm{mg}$; Colorless oil : ${ }^{1} \mathrm{HNMR} \delta$ $\left(400 \mathrm{MHz}, \mathrm{CDCl}_{3}\right)$ 7.36-7.38 (m, 2H), 6.89-6.92 (m, 2H), 3.82 (s, 3H), 3.69 (brs, 2H), 3.45 (brs, 2H), 1.64 (brs, 4H), 1.60 (br, 2H)

9. $\quad N$-(p-Chlorobenzoyl) piperidine: yield $81 \%, 180 \mathrm{mg}$; Colorless oil: ${ }^{1} \mathrm{H}$ NMR $\delta(400 \mathrm{MHz}$, $\mathrm{CDCl}_{3}$ ) 7.28-7.39 (m, 4H), 3.69 (brs, 2H), 3.33 (brs, 2H), 1.68 (brs, 4H), 1.52 (br, 2H). 
10. Methyl 2-benzamidoacetate: yield 64\%, $124 \mathrm{mg}$; white solid. ${ }^{1} \mathrm{H}$ NMR $\left(\mathrm{CDCl}_{3}, 400 \mathrm{MHz}\right) \delta$ $7.80(\mathrm{~m}, 2 \mathrm{H}), 7.47(\mathrm{~m}, 1 \mathrm{H}, J=7.6 \mathrm{~Hz}), 7.34(\mathrm{~m}, 2 \mathrm{H}, J=7.6 \mathrm{~Hz}), 6.98(\mathrm{bs}, 1 \mathrm{H}), 4.18(\mathrm{q}, 2 \mathrm{H}, J=6.8 \mathrm{~Hz})$, $4.16(\mathrm{~d}, 2 \mathrm{H}, J=5.2 \mathrm{~Hz}), 1.25(\mathrm{t}, 3 \mathrm{H}, J=6.8 \mathrm{~Hz})$.

11. Methyl 2-(4-nitrobenzamido)acetate: yield $81 \%, 193 \mathrm{mg}()$; white solid. ${ }^{1} \mathrm{H}$ NMR $\left(\mathrm{CDCl}_{3}, 400\right.$ MHz) $\delta 8.37-8.35(\mathrm{~d}, 2 \mathrm{H}, J=8.4 \mathrm{~Hz}), 7.96-7.94(\mathrm{~d}, 2 \mathrm{H}, J=8.4 \mathrm{~Hz}), 6.94(\mathrm{bs}, 1 \mathrm{H}), 4.28-4.21(\mathrm{~m}, 4 \mathrm{H})$, $1.31(\mathrm{q}, 3 \mathrm{H}, J=7.2 \mathrm{~Hz})$

12. Methyl 2-benzamido-3-methylbutanoate: yield 59\%, $138 \mathrm{mg}$; white solid. ${ }^{1} \mathrm{H} \mathrm{NMR}\left(\mathrm{CDCl}_{3}\right.$, $400 \mathrm{MHz}) \delta 7.79(\mathrm{~m}, 2 \mathrm{H}, J=7.2 \mathrm{~Hz}), 7.48(\mathrm{~m}, 1 \mathrm{H}, J=7.2 \mathrm{~Hz}), 7.41(\mathrm{~m}, 2 \mathrm{H}, J=7.2 \mathrm{~Hz}), 6.69(\mathrm{~d}, 1 \mathrm{H}, \mathrm{J}=$ $8.4 \mathrm{~Hz}), 4.72(\mathrm{~m}, 1 \mathrm{H}, \mathrm{J}=8.8,8.8 \mathrm{~Hz}), 3.71(\mathrm{~s}, 3 \mathrm{H}), 2.25(\mathrm{~m}, 1 \mathrm{H}), 0.96(\mathrm{~m}, 6 \mathrm{H})$.

\section{RESULTS AND DISCUSSION}

As a model reaction we have taken benzaldehyde (1 equiv.) and para nitrophenol (1.5 equiv.)in an over dried round bottom flask. With catalytic amounts of simple tetrabutylammonium bromide $\left(\mathrm{nBu}_{4} \mathrm{NBr}\right)$ as the precatalyst and a solution of tert-butyl hydrogen peroxide (TBHP) in decane as co-oxidant at room temperature, the reaction was continued to stir at specified temperature. After the disappearance of the spot corresponding to aldehyde in TLC we have added amount of benzyl amine (1.2 equiv.). The following Table-1 is the standardization results from which it is clear that $10 \mathrm{~mol} \%$ of catalyst and 1.5 equivalent of PNP and 1.2 equivalent of amine.

Table-1: Standardization

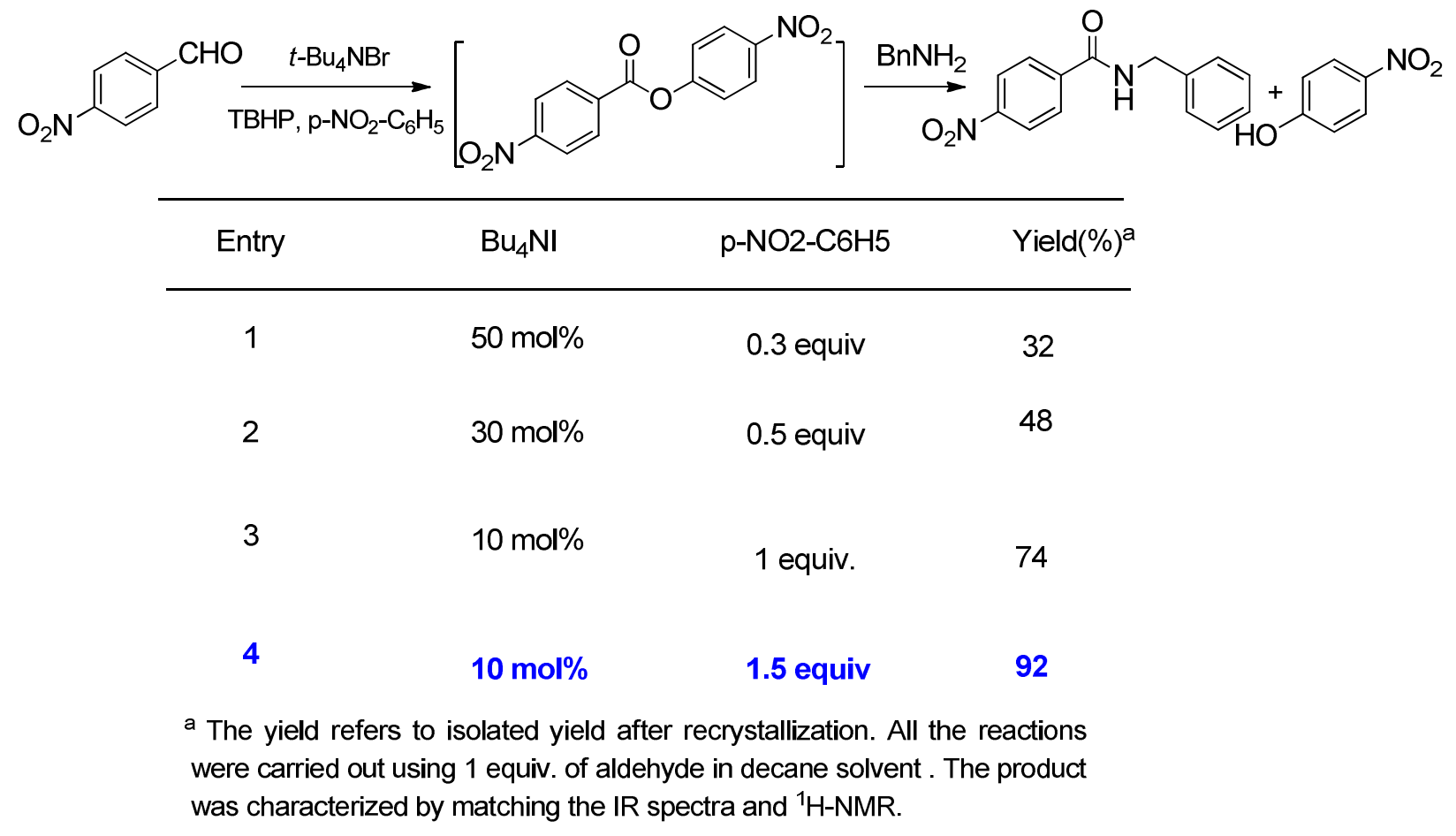

In order to explore the scope of the present methodology for various molecules with different groups, we have studied with appropriate examples that are tabulated in the following Table-2. The methodology that we have developed is quite general for the condensation of aromatic aldehydes and aliphatic amines. But the attempts to carry out the transformation between aliphatic aldehydes and PNP did not progress under 
Vol. 10 | No. 2 |333 -338 | April - June | 2017

Table-2: Substrate scope for amides

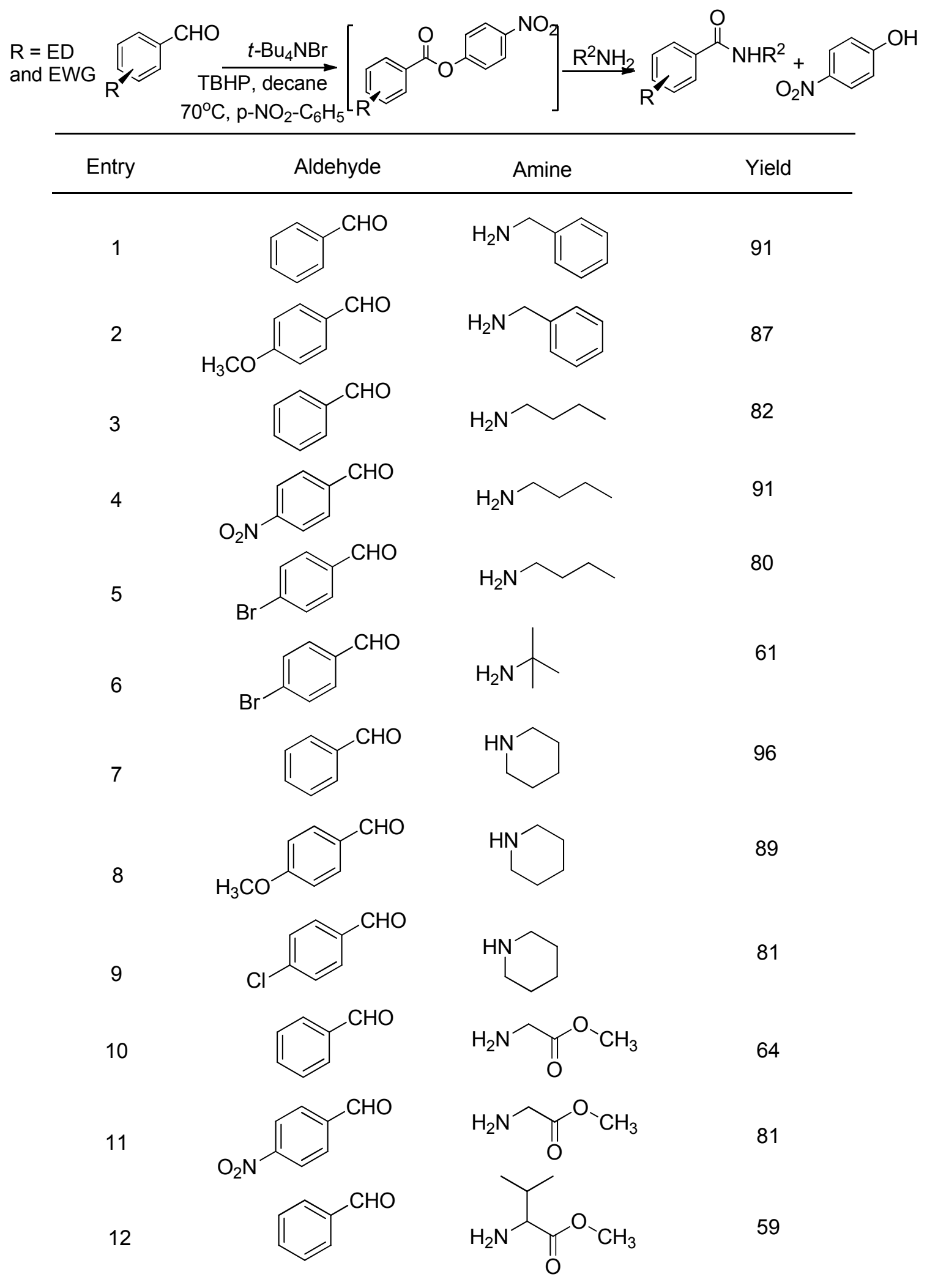


the described conditions. However, PNP activated esters of carboxylic acids were very much known in the literature and could be used for the verities of amines to furnish respective amides. Though it was a limitation for the present methodology, it could have been successfully employed for the synthesis of aromatic amides. The aliphatic amines underwent the reaction smoothly. Notably, the present methodology is sensitive for the presence of electron donating and withdrawing effects of the substituents. The presence of electron donating group at para position of the aldehyde benzene ring decreased the yield than the case in which it is absent (entry 1 and 2, Table-2). The same effect was also seen in the entry 3 and 4 and entry 7, and 8,9 also. On the other hand, the presence of an electron withdrawing group increased the yield of the final product (entry 3, 4 and 10 and 11, Table-2). Therefore, it can be generalized that the presence of electron donating group at $4^{\text {th }}$ position would decrease the yield and the presence of an electron withdrawing group promotes the formation of the product in agreement with the theory. The low yield of the entry 12, Table-2, could be attributed for the steric bulkiness of the side chain of the amino acid. Additionally, entry 1, Table- 2 has been attempted on $5 \mathrm{~g}$ scale as well and interestingly, the product isolated was almost the same (90\%).Furthermore, the activated ester is characterized for tor entry 1, table 2 using the IR spectra ${ }^{1} \mathrm{H}$ NMR and therefore, the formation of activated ester in the present case un debatable. All the products were well reported in the literature and each of the amide made was characterized from IR and ${ }^{1} \mathrm{H}$ NMR. All the reactions were carried out with respect to 1 mole of the aldehyde. Every time the PNP ester was recovered and recycled which is an important aspect of the green chemistry practice.

\section{CONCLUSION}

In conclusion, we have demonstrated a method for the synthesis of amides and esters from the aldehydes through the well-known para nitro phenol ester activation. The yields are quite good and the reactions are faster. The problems that are associated with purification of these molecules with DCC/DMAP could be precluded by this method. Furthermore, the auxiliary that is used to activate, could have been recovered and re employed for several reactions. Even the reaction was carried out on a gram scale and the yield was found to be relatively good as well. The catalyst employed was catalytic (10mol \%) and very cheap. The substrate scope is reasonably good and furnished the respective amides and esters in excellent yields. The present methodology limits its application to only the aromatic aldehydes and our attempts to carry out the transformation with aliphatic aldehydes were not fruitful. Importantly, the presence of electron withdrawing group on the aldehyde at an appropriate position, promoted the reaction whereas the presence of electron releasing group on it decreased the yield. Similar to this observation, the presence of electron withdrawing group on the phenolic part also increased the yield while the substituent with other effect decreased the yield.

\section{ACKNOWLEDGMENT}

The authors thank the management P. B. Sidhartha College and K. B. N. College Vijayawada for enabling us to carry out this project. The authors also thank Dr. Nani Babu Palakurthy for helping in preparing the manuscript.

\section{REFERENCES}

1. (a.)M. J. Humphrey, R. A. Chamberlin, Chem. Rev., 97,224 (1997); (b.)R. M.Wilson, J. L. Stockdill, X.Wu, X. Li, P. A. Vadola, P. K. Park, P. Wang, S. J. Danishefsky, Angew. ChemInt. Ed., 124, 2888 (2012); (c.) V. R. Pattabiraman, J.W. Bode, Nature, 480, 471 (2012); (d.) M. Bodanzsky, Principles of Peptide Synthesis 2nd ed., Springer, New York, 199.

2. (a.) L. A. Carpino, J. Am. Chem. Soc., 115, 4397 (1993); (b.) J. C. Sheehan, G. P. Hess, J. Am. Chem. Soc.77, 1067 (1955); (c.) A. El- Faham, F. Albericio, Chem. Rev., 111, 6557 (2011); (d.) C. Najera, Syn. let., 9, 1388 (2002).

3. (a.)I. Abdelmoty, F. Albericio, L.A. Carpino, B. M. Foxman, S.A. Kates, Lett. Pept. Sci., 1, 57 (1994); (b.) A. El-Faham, F. Albericio, J. Org. Chem. 73, 2731 (2008),

4. (a.)W. Yoo, C. Li, J. Am. Chem. Soc. 128, 13064 (2006); (b.) K. Ekoue-Kovi, C.Wolf, Org. Lett. 9, 3429 (2007); (c.) C. L. Allen, S. Davulcu, J. M. J. Williams, Org. Lett. 12, 5096 (2010); (d.) C. 
RASĀYAN $J$. Chem.

Vol. 10 | No. 2 |333 -338 | April - June | 2017

Zhang, Z. Xu, L. Zhang, N. Jiao.Angew. Chem. Int. Ed. 50, 11088 (2011); (e.) S. C. Ghosh, J. S. Y. Ngiam, C. L. L. Chai, A. M. Seayad, T. T. Dang, A. Chen, Adv. Synth. Catal. 354, 1407 (2012).

5. (a.) K. Y. K. Chow, J.W. Bode, J. Am. Chem. Soc.126, 8126 (2004); (b.) N. Y. Reynolds, J. R. deAlaniz, T. Rovis, J. Am. Chem. Soc. 126, 9518 (2004); (c.) R. M. Al-Zoubi, O. Marion, D. G. Hall. Angew. Chem. Int. Ed. 47, 2876 (2008); (d.) S. D. Sarkar, S. Grimme, A. Studer, J. Am. Chem. Soc.132, 1190 (2010); (e.) C. L. Allen, B. N. Atkinson, J. M. J. Williams. Angew. Chem. Int. Ed. 51, 1383 (2012); (f.) T. B. Nguyen, J. Sorres, M. Q. Tran, L. Ermolenko, A. Al-Mourabit, Org. Lett. 14, 3202 (2012); (g.) E. E. Finney, K. A. Ogawa, A. J. Boydston, J. Am. Chem. Soc. 134, 12374 (2012); (h.) B. Tan, N. Toda, C. F. Barbas III. Angew. Chem. Int. Ed. 51, 12538 (2012); (i.) G. Majji, S. Guin, A. Gogoi, S. K. Rout, B. K. Patel. Chem. Commun.49, 3031 (2013); (j.) D. Leow. Org. Lett., 16, 5812 (2014).

[RJC-1625/2017] 